\title{
RELIGIOUS TOURISM IN A REGION: CURRENT STATE AND PROSPECTS OF DEVELOPMENT (BASED ON VOLGOGRAD REGION)
}

\author{
Olga A. Balabeykina \\ Saint-Petersburg State University of Economics, Saint Petersburg, Russian Federation
}

\begin{abstract}
Religious tourism has gained an increasing role throughout the world. Due to its initial component, pilgrimage, it is often considered the oldest form of tourism, dating thousands of years back. The paper is devoted to the analysis of the current state and prospects of the religious tourism development within the framework of the Orthodox doctrine on the example of Volgograd region. Using statistical and mathematical-economic methods, the author makes an assessment of the level of development of the industry and identifies strengths and weaknesses in the current economic system. In addition, the work investigates the unique infrastructural complex comprising numerous places of high religious importance. The choice of key and peripheral directions of a possible tourist flow is justified based on regional statistical data (including the number of cultural objects). The main reasons determining the development of the industry are also explained. The author defines the most important factors of attracting pilgrims and tourists for each large object of Volgograd region. Based on the SWOT-analysis method the author assesses the potential of the tourism development and finds promising and limiting aspects that can affect the future of the industry. The existing offer of tourist services is considered, and on the basis of unique qualities of Volgograd region the author points out alternatives and expansion possibilities for the existing religious tourism services.
\end{abstract}

Key words: religious tourism, pilgrimage, Volgograd region, religious tourism objects, objects of religious worship, prospects for the development of religious tourism, monument of the Orthodox Christianity culture.

Citation. Balabeykina O.A. Religious Tourism in a Region: Current State and Prospects of Development (Based on Volgograd Region). Journal of Volgograd State University. Economics, 2020, vol. 22, no. 1, pp. 83-94. (in Russian). DOI: https://doi.org/10.15688/ek.jvolsu.2020.1.8

\section{РЕЛИГИОЗНЫЙ ТУРИЗМ В РЕГИОНЕ: СОВРЕМЕННОЕ СОСТОЯНИЕ И ПЕРСПЕКТИВЫ РАЗВИТИЯ (НА ПРИМЕРЕ ВОЛГОГРАДСКОЙ ОБЛАСТИ)}

\section{Ольга Александровна Балабейкина}

Санкт-Петербургский государственный экономический университет, г. Санкт-Петербург, Российская Федерация

Аннотация. Религиозный туризм приобретает все большую роль во всех уголках земного шара. Благодаря своей первоначальной составляющей - паломничеству - он часто считается старейшей формой туризма, существовавшей и тысячелетия назад. В статье рассматривается современное состояние и перспективы развития религиозного туризма в рамках православного вероучения на примере Волгоградской области. С помощью статистических и экономико-математических методов автором была проведена оценка уровня развития обозначенной отрасли. В работе изучен инфраструктурный комплекс, имеющий историко-культурную ценность с точки зрения религиозного туризма и заключенный в большом числе православных храмов, монастырей. На основании статистических данных о территории региона и количестве культурных объектов выявлены главные причины, определяющие развитие отрасли, и обоснован выбор ключевых и периферийных направлений возможного туристического потока. Определены важнейшие факторы привле-
} 
чения паломников и туристов для каждого крупного объекта Волгоградской области. На основе SWOTанализа проведена оценка потенциала развития туризма, найдены перспективные и лимитирующие аспекты, способные отразиться на будущем отрасли. Рассмотрено имеющееся предложение туристических услуг и на основе уникальных качеств Волгоградской области предложены варианты и рекомендации расширения экскурсионных услуг религиозной направленности.

Ключевые слова: религиозный туризм, паломничество, Волгоградская область, объекты религиозного туризма, объекты культового назначения, перспективы развития религиозного туризма, памятник православной культуры.

Цитирование. Балабейкина О. А. Религиозный туризм в регионе: современное состояние и перспективы развития (на примере Волгоградской области) // Вестник Волгоградского государственного университета. Экономика. -2020. - T. 22, № 1. - C. 83-94. - DOI: https://doi.org/10.15688/ek.jvolsu.2020.1.8

\section{Введение}

Актуальность научных исследований, связанных с рассмотрением различных аспектов функционирования религиозного туризма на национальном и региональном уровнях, обусловлена тем, что данное направление рекреационного хозяйства в последние десятилетия характеризуется как перспективное и динамично развивающееся в нашей стране. Высокий спрос на маршруты религиозного туризма и интерес к объектам культовой инфраструктуры среди населения России и многих стран мира позволяют говорить об этой ветви туризма, как о значимой для экономического развития территорий, обладающих соответствующим историко-культурным потенциалом, и поддержания социальной стабильности. На динамичность развития обозначенной отрасли рекреационного хозяйства в последние годы и востребованность маршрутов религиозной тематики среди населения указывают не только отечественные, но и зарубежные ученые [Griffin et al., 2017].

Значение религиозного туризма в экономике страны и региона обусловлено тем, что дополнительные услуги, начиная от транспортных перевозок и заканчивая медицинским обслуживанием, изначально включены в «стандартный пакет» паломника или туриста, путешествующего маршрутом познавательной направленности с религиозной тематикой, что как раз и составляет мультипликативный эффект, влекущий за собой развитие отраслей хозяйства, задействованных в обслуживании туристов.

Религиозный туризм как новое направление в отечественных экономических исследованиях за сравнительно короткий период своего становления и развития в нашей стране неоднократно привлекал внимание ученых, осуществлявших разработки в области маркетинга территории [Ванчикова и др., 2014], экономики и развития региона [Крылов, 2011], экономики туризма, торговли и сферы услуг [Оганесян, 2013] и др.

Зарубежные исследователи также неоднократно представляли результаты научного осмысления различных аспектов, связанных с организацией и развитием основных видов религиозного туризма. Так, например, объектом исследования румынского ученого В. Пушкашу выступают как теоретико-методологические вопросы, вокруг которых ведутся научные дискуссии, в частности, соотношение понятий «религиозный туризм» и «паломничество», так и способы решения практических задач, вызванных функционированием данной отрасли туризма, например, повышение его эффективности в национальной и региональной экономике [Puşcaşu, 2015].

Несмотря на большое количество, тематическое разнообразие и широкий территориальный охват отечественных и зарубежных исследований, посвященных религиозному туризму и его разновидностям, за довольно редким исключением они носят описательный характер и посвящены выявлению наиболее интересных и перспективных объектов культовой инфраструктуры и маршрутов данной направленности в регионе. В связи с этим в настоящий момент ощущается потребность в научно-методических разработках, содержащих способы оценки современного состояния и тенденций развития религиозного туризма в регионе.

Цель данной работы - представление комплексного подхода к вопросу изучения со- 
стояния и перспектив развития религиозного туризма в рамках православного вероучения на уровне отдельного субъекта Российской Федерации. В качестве объекта исследования выступает религиозный туризм Волгоградской области, чье население характеризуется этническим и конфессиональным разнообразием ввиду уникального транспортно-географического расположения региона, а территория отличается большим количеством объектов православной культовой инфраструктуры и наличием уникальных сакральных мест, маршруты для посещения которых пользуются спросом у паломников и туристов [Краснова и др., 2016]. При этом стоит учитывать тот факт, что в Волгоградской области в силу целого ряда причин (исторических, политических и т. д.) отсутствуют древние и особенно ценные в сакральном плане памятники православной культуры, являющиеся главными составляющими брендинга территории в ряде регионов центра и северо-запада РФ [Пикулева, 2012; Сукманова, 2015]. Тем не менее перспективы для развития религиозного туризма открываются и в отсутствии данного преимущества.

\section{Методика исследования}

В процессе данного исследования нашли применение статистические и экономико-математические методы, ранее не использовавшиеся в области изучения вопросов функционирования религиозного туризма; метод SWOT-анализа, который позволил автору выявить основные проблемы и перспективы развития обозначенной отрасли рекреационного хозяйства в регионе с точки зрения методологии.

\section{Результаты и обсуждение}

Будучи одним из элементов культурного туризма, религиозный туризм включает в себя весь спектр туристических путешествий, которые традиционно подразделяются на внутренние и зарубежные, однодневные и многодневные, групповые и индивидуальные и т. д. Отличительной чертой классификации религиозного туризма является выделение в его рамках разных подвидов, где основным кри- терием дифференциации выступает цель, с которой пользователь услуги религиозного туризма избирает маршрут в рамках данного направления. При том, что универсальный теоретико-методологический аппарат, отражающий основные научные понятия, связанные с изучением функционирования и развития обозначенной отрасли рекреационного хозяйства, нельзя считать окончательно оформленным, исследователями преимущественно выделяются паломничество и религиозный туризм экскурсионно-познавательной направленности. Обоснованным представляется добавление к этим двум формам религиозного туризма третьей, подразумевающей универсальные специализированные туры, объединяющие интересы как паломников, так и экскурсантов.

Научные публикации, посвященные теоретическим вопросам и уточнению значения дефиниций, связанных с видами религиозного туризма, довольно многочисленны и даже, можно сказать, составляют отдельное направление исследований в рамках этой сравнительно новой ветви в российской науке [Лагусева, 2017; Якунин, 2017; и др.]. Но при большом разнообразии авторских подходов к критериям выделения видов религиозного туризма и определению основных понятий, связанных с данной категорией, теоретические дискуссии вокруг них продолжаются.

Анализ содержания теоретических работ - российских и зарубежных, - посвященных этой тематике, позволил выявить определенные тенденции в развитии данного направления исследований, а также обозначить смысл и содержание ключевых понятий, которыми в дальнейшем мы будем оперировать.

Религиозный экскурсионно-познавательный туризм и паломничество понимаются как виды отраслевого туризма общей тематической направленности. По сути, паломничество отличают от других видов туризма его цели духовные. Паломнический тур предполагает участие в богослужениях и других религиозных практиках (таинствах, обрядах), заведомо включенных в программу маршрута и позиционирующихся как его доминанта.

Полярности на воображаемой оси паломничества-туризма обозначены как религиозно обусловленные по сравнению с секулярными. Между ними пролегает очень широкий 
диапазон возможных религиозно-секулярных комбинаций, причем центральную область на такой воображаемой схеме чаще всего принято в научных работах называть «религиозным туризмом экскурсионно-познавательной направленности».

Основным отличием религиозного туризма экскурсионно-познавательной направленности от паломничества выступает цель посещения туристами религиозных объектов, которая в данном случае больше сводится к ознакомительной или просветительской, чем к религиозно-практической, хотя туристы в рамках маршрутов обозначенного типа могут посещать богослужения, становиться участниками крестных ходов, молебнов, церковных обрядов и таинств.

Туристско-рекреационный и историкокультурный потенциал Волгоградской области, заключенный в большом числе православных храмов и монастырей, чудотворных икон и других сакральных мест, позволяет развивать на ее территории все направления религиозного туризма. Построенные или восстановленные в постсоветский период православные храмы и часовни Волгограда вовлекаются и в исторические маршруты познавательного туризма, становясь неотъемлемой частью последних. В качестве примера могут служить действующие храм Всех Святых и храм-часовня в честь Владимирской иконы Божией Матери, ставшие архитектурными доминантами мемориального кладбища Мамаева Кургана.

Именно спрос на маршруты религиозной тематики и разнообразие объектов православной культовой инфраструктуры послужили основанием для открытия в 2004 г. паломнического центра Волгоградской епархии [Галкова и др., 2015, с. 175], на данный момент довольно успешно функционирующего и организующего самые разнообразные виды паломнических и религиозно-просветительских поездок.

Анализ предложения на рынке религиозного туризма Волгоградской области позволил выявить его структуру. Маршруты религиозной тематики подготавливают к реализации и осуществляют в основном три организации - Паломническая служба Волгоградской митрополии Русской Православной Церкви [Единый паломнический центр ...], а также туристические фирмы «Туризм Волгоград» [Туризм Волгоград РФ] и «Волгоград-спутник» [Экскурсии и туры ...]. При этом Паломническая служба Волгоградской митрополии предлагает более широкий перечень услуг, то есть как паломнические, так и просветительские туры, а светские фирмы продают путевки исключительно в религиозно-познавательные поездки. Приобрести возможность отправиться в путешествие по маршруту религиозно-познавательной тематики можно и через разветвленную дилерскую сеть, образованную двумя упомянутыми туристическими фирмами.

В ходе анализа предложения религиозного туризма в Волгоградской области были выявлены православные монастыри и храмы, наиболее часто задействованные как объекты посещения на разнообразных маршрутах соответствующей тематики, берущие начало из г. Волгограда. Далее перечень культовых объектов районов Волгоградской области в скобках содержит количество упоминаний храма или монастыря на самих паломнических и религиозно-познавательных маршрутах: Богородице-Ахтырский женский монастырь, с. Гусевка (12); Кременской Вознесенский мужской монастырь, Клетской р-н (12); УстьМедведицкий Спасо-Преображенский женский монастырь, г. Серафимович (11); Каменно-Бродский Свято-Троицкий мужской монастырь, Ольховский р-н, (10); Свято-Вознесенский женский монастырь, г. Дубовка (9); кафедральный собор Покрова Пресвятой Богородицы, г. Урюпинск (4); храм св. ап. апостолов Петра и Павла, с. Лог (4); храм Рождества Пресвятой Богородицы г. Фролово (2); Никольский кафедральный собор, г. Камышин (1).

Волгоградская митрополия Русской Православной Церкви, в границах совпадающая с одноименной областью, делится на три епархии, насчитывающих более 200 объектов православной культовой инфраструктуры (соборов, приходских храмов, часовен и монастырей) [Соборы.Ру ...]. Правда, в это число вошли и те из них, которые находятся в заброшенном или полуразрушенном состоянии, а действующих - около 130 (см. табл. 1). Они размещены на территории региона крайне неравномерно, что нашло графическое отображение с помощью кривой Лоренца, составленной на основа- 
O.А. Балабейкина. Религиозный туризм в регионе: современное состояние и перспективы развития

нии соотношения статистических данных площади районов Волгоградской области и числа объектов православной культовой инфраструктуры на их территории (см. рисунок).

Неравномерность размещения православных храмов, монастырей и часовен, посещение которых представляет реальный или потенциальный интерес для предъявителей спроса на религиозно-познавательные и паломнические маршруты, позволила, опираясь на число объектов православной культовой инфраструктуры, наиболее востребованных в ходе осуществления маршрутов религиозной тематики, выделить на территории Волгоградской области три региона, составляющих ядро, полупериферию и периферию.

Ядро развития религиозного туризма в Волгоградской области составляют храмы и монастыри, расположенные в следующих ее административных районах: Городищенском,

Таблица 1

\section{Степень равномерности размещения объектов} православной культовой инфраструктуры в Волгоградской области

\begin{tabular}{|c|c|c|c|c|c|c|c|}
\hline Район & $\begin{array}{l}\text { Площадь, } \\
\text { тыс. км кв. }\end{array}$ & $\begin{array}{c}\text { Объекты, } \\
\text { шт. }\end{array}$ & $\begin{array}{c}\text { Доля рай- } \\
\text { она в об- } \\
\text { щей пло- } \\
\text { щади }\end{array}$ & $\begin{array}{c}\text { Доля } \\
\text { объекта }\end{array}$ & $\begin{array}{c}\text { К-т нерав- } \\
\text { номерно- } \\
\text { сти }\end{array}$ & $\begin{array}{c}\text { К-т пре- } \\
\text { имущества }\end{array}$ & Ранг \\
\hline Алексеевский р-н & 2,30 & 8 & 0,02 & 0,03 & $-0,01$ & 1,64 & 30 \\
\hline Быковский р-н & 3,41 & 2 & 0,03 & 0,01 & 0,02 & 0,28 & 8 \\
\hline г. Волгоград & 0,86 & 68 & 0,01 & 0,29 & $-0,28$ & 36,13 & 34 \\
\hline Городищенский р-н & 2,18 & 7 & 0,02 & 0,03 & $-0,01$ & 1,51 & 24 \\
\hline Даниловский р-н & 2,96 & 2 & 0,03 & 0,01 & 0,02 & 0,32 & 29 \\
\hline Дубовский р-н & 3,14 & 12 & 0,03 & 0,05 & $-0,02$ & 1,80 & 9 \\
\hline Еланский р-н & 2,67 & 1 & 0,02 & 0,00 & 0,02 & 0,18 & 31 \\
\hline Жирно вский р-н & 2,97 & 3 & 0,03 & 0,01 & 0,01 & 0,48 & 2 \\
\hline Иловлинский р-н & 4,16 & 8 & 0,04 & 0,03 & 0,00 & 0,91 & 12 \\
\hline Калачевский р-н & 4,23 & 9 & 0,04 & 0,04 & 0,00 & 1,00 & 23 \\
\hline Камышинский р-н & 3,56 & 10 & 0,03 & 0,04 & $-0,01$ & 1,32 & 25 \\
\hline Киквидзенский р-н & 2,07 & 1 & 0,02 & 0,00 & 0,01 & 0,23 & 28 \\
\hline Клетский р-н & 3,56 & 4 & 0,03 & 0,02 & 0,01 & 0,53 & 4 \\
\hline Котельниковский р-н & 3,47 & 4 & 0,03 & 0,02 & 0,01 & 0,54 & 14 \\
\hline Котовский р-н & 2,44 & 1 & 0,02 & 0,00 & 0,02 & 0,19 & 15 \\
\hline Кумылженский p-н & 2,96 & 3 & 0,03 & 0,01 & 0,01 & 0,48 & 3 \\
\hline Ленинский р-н & 2,60 & 3 & 0,02 & 0,01 & 0,01 & 0,54 & 13 \\
\hline г. Михайловка & 3,60 & 7 & 0,03 & 0,03 & 0,00 & 0,92 & 16 \\
\hline Нехаевский р-н & 2,18 & 5 & 0,02 & 0,02 & 0,00 & 1,08 & 26 \\
\hline Николаевский р-н & 3,44 & 2 & 0,03 & 0,01 & 0,02 & 0,27 & 7 \\
\hline Ново аннинский р-н & 3,08 & 5 & 0,03 & 0,02 & 0,01 & 0,77 & 21 \\
\hline Новониколаевский р-н & 2,36 & 3 & 0,02 & 0,01 & 0,01 & 0,60 & 18 \\
\hline Октябрьский р-н & 3,81 & 2 & 0,03 & 0,01 & 0,03 & 0,25 & 6 \\
\hline Ольховский р-н & 3,23 & 3 & 0,03 & 0,01 & 0,02 & 0,44 & 10 \\
\hline Палласовс кий р-н & 12,36 & 1 & 0,11 & 0,00 & 0,11 & 0,04 & 1 \\
\hline Руднянский р-н & 1,95 & 3 & 0,02 & 0,01 & 0,00 & 0,73 & 19 \\
\hline Светлоярский р-н & 3,19 & 6 & 0,03 & 0,03 & 0,00 & 0,89 & 22 \\
\hline Серафимовичский p-н & 4,32 & 7 & 0,04 & 0,03 & 0,01 & 0,76 & 20 \\
\hline Среднеахтубинский р-н & 1,96 & 14 & 0,02 & 0,06 & $-0,04$ & 3,38 & 33 \\
\hline Старополтавский р-н & 4,08 & 2 & 0,04 & 0,01 & 0,03 & 0,23 & 5 \\
\hline Суровикинский р-н & 3,40 & 4 & 0,03 & 0,02 & 0,01 & 0,56 & 17 \\
\hline Урюпинский р-н & 3,47 & 17 & 0,03 & 0,07 & $-0,04$ & 2,31 & 32 \\
\hline Фроловс кий р-н & 3,26 & 8 & 0,03 & 0,03 & 0,00 & 1,16 & 27 \\
\hline Чернышковский p-н & 3,08 & 3 & 0,03 & 0,01 & 0,01 & 0,46 & 11 \\
\hline Итого & 112,29 & 238 & - & - & 0,42 & - & - \\
\hline
\end{tabular}

Примечание. Составлено автором. 
Дубовском, Иловлинском, Калачевском, Ольховском, Светлоярском, Среднеахтубинском (храмы последнего преимущественно значимой архитектурной и сакральной ценности не представляют, но могут быть вовлечены в тематические маршруты как объекты показа благодаря географическому положению района). Все они находятся в центральной части Волгоградской области, образованной междуречьем Волги и Дона, на Приволжской возвышенности. Здесь же расположен административный центр области г. Волгоград, на территории которого действуют более 60 православных храмов и часовен, правда, большая часть из которых - типовые постройки 1990-х - начала 2000-х гг., не представляющие интереса для паломников и туристов. При этом их следует учитывать, оценивая туристско-рекреационный потенциал территории в плане развития религиозного туризма, так как статус аттрактивных центров и пунктов, составляющих маршруты данной направленности, может в короткие сроки трансформироваться, благодаря размещению в храмах почитаемых икон, мощей святых, открытию источников святой воды и т. д. [Артемьева и др., 2019].

Ниже представлена таблица, отражающая сакральную и историко-архитектурную ценность наиболее часто задействованных (или имеющих потенциал быть задействованными) на марш- рутах обозначенной тематики объектов православной культовой инфраструктуры административных районов Волгоградской области, образующих ядро развития религиозного туризма на территории данного субъекта РФ (см. табл. 2).

Ядро развития православного религиозного туризма в Волгоградской области сложилось благодаря целому ряду факторов. Вопервых, это разнообразие объектов православной культовой инфраструктуры - монастырей и храмов на данной территории. Некоторые объекты, например, обладающий уникальной ценностью для верующих православных людей храм Никиты Гофтского с поновляющимися иконами и зафиксированным явлением мироточения в с. Дубовый Овраг, могут быть вовлечены в большое количество паломнических и экскурсионных маршрутов религиознопознавательной направленности благодаря транспортной доступности и близкому расположению к г. Волгограду. Отличительной чертой, формирующей брендинг территории Волгоградской области в плане развития религиозного православного туризма, можно считать наличие плавучих храмов, осуществляющих миссионерские речные круизы. Для ядра развития религиозного туризма характерна насыщенность маршрутов объектами показа и религиозного поклонения.

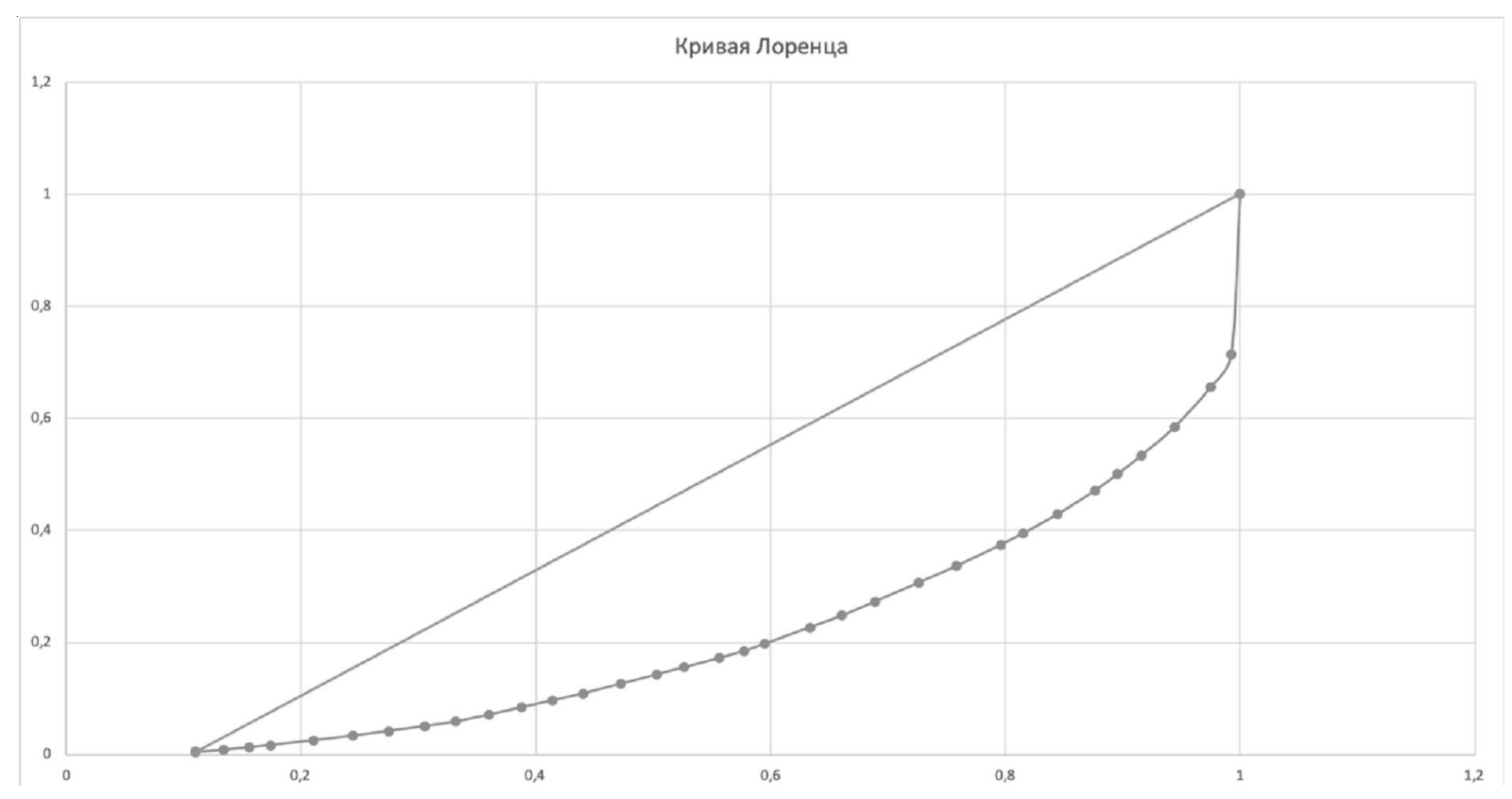

Рисунок. Равномерность размещения объектов православной культовой инфраструктуры в Волгоградской области (кривая Лоренца)

Примечание. Составлено автором по: [Соборы.Ру; Калинина и др., 2011]. 
Объекты православной инфраструктуры ядра развития религиозного туризма Волгоградской области

\begin{tabular}{|c|c|c|}
\hline Объект религиозного туризма & Район & $\begin{array}{c}\text { Факторы привлечения паломников и туристов } \\
\text { (сакральная, историко-архитектурная ценность, } \\
\text { транспортная доступность и т. д.) }\end{array}$ \\
\hline $\begin{array}{l}\text { Собор Казанской иконы Божией } \\
\text { Матери }\end{array}$ & г. Волгоград & $\begin{array}{l}\text { Кафедральный собор Волгоградской и Камышин- } \\
\text { ской епархии РПЩ }\end{array}$ \\
\hline Храм Всех Святых & г. Волгоград & $\begin{array}{l}\text { Храм-памятник в честь разгрома немецко- } \\
\text { фашистских войск, расположен на высоте } 102,0 \text { м } \\
\text { (высота Мамаева Кургана на картах) }\end{array}$ \\
\hline $\begin{array}{l}\text { Храм св. равноап. князя Влади- } \\
\text { мира }\end{array}$ & г. Волгоград & $\begin{array}{l}\text { Плавучий храм, оборудованный на бывшем десант- } \\
\text { ном корабле }\end{array}$ \\
\hline $\begin{array}{l}\text { Храм Живоносного источника } \\
\text { Апостола и Евангелиста Иоанна } \\
\text { Богослова }\end{array}$ & г. Волгоград & $\begin{array}{l}\text { Пойма р. Царица. Рядом с храмом расположен из- } \\
\text { вестный с } 1909 \text { г. живоносный источник святого } \\
\text { апостола Иоанна Богослова }\end{array}$ \\
\hline $\begin{array}{l}\text { Храм Иоанна Предтечи (подво- } \\
\text { рье Свято-Вознесенского Дубов- } \\
\text { ского женского монастыря) }\end{array}$ & г. Волгоград & $\begin{array}{l}\text { Восстановлена на месте самого древнего храма го- } \\
\text { рода (XVII в.), разрушенно го в } 1930 \text {-х годах }\end{array}$ \\
\hline Храм Иосифа Астраханского & г. Волгоград & $\begin{array}{l}\text { На кладбище при храме находится могила местноч- } \\
\text { тимой блаженной Марфы Царицынской }\end{array}$ \\
\hline Храм Никиты Мидикийского & г. Волгоград & $\begin{array}{l}\text { Единственный сохранившийся в Волгограде храм } \\
\text { ХVIII века }\end{array}$ \\
\hline $\begin{array}{l}\text { Храм в честь иконы Богоматери } \\
\text { «Всех скорбящих Радость» }\end{array}$ & $\begin{array}{l}\text { Городищенский, } \\
\text { пос. Городище }\end{array}$ & $\begin{array}{l}\text { Единственный в области храм, выдержанный в ви- } \\
\text { зантийском стиле }\end{array}$ \\
\hline $\begin{array}{l}\text { Свято-Вознесен ский } \\
\text { монастырь }\end{array}$ & $\begin{array}{l}\text { Дубовский, } \\
\text { г. Дубовка }\end{array}$ & $\begin{array}{l}\text { «Город дубов», родник «Гремучий», Церковь По- } \\
\text { крова Божией Матери }\end{array}$ \\
\hline $\begin{array}{l}\text { Кременско-Вознесенский муж- } \\
\text { ской монастырь }\end{array}$ & $\begin{array}{l}\text { Иловлинский, } \\
\text { хуг. Саушкин }\end{array}$ & Свято-Троицкая церковь \\
\hline $\begin{array}{l}\text { Храм первоверховных апостолов } \\
\text { Петра и Павла }\end{array}$ & $\begin{array}{l}\text { Иловлинский, } \\
\text { хуг. Лог }\end{array}$ & Чудотворная икона Казанской Божией Матери \\
\hline Храм святителя Иннокентия & $\begin{array}{l}\text { Калачевский, } \\
\text { пос. Пятиморск } \\
\end{array}$ & Плавучий храм в период с 1998 по 2011 год \\
\hline $\begin{array}{l}\text { Храм святого Николая } \\
\text { творца }\end{array}$ & $\begin{array}{l}\text { Калачевский, } \\
\text { ст. Голубинская }\end{array}$ & Каменный храм конца XIX века \\
\hline $\begin{array}{l}\text { Каменно-Бродский } \quad \text { Свято- } \\
\text { Троицкий мужской монастырь } \\
\end{array}$ & $\begin{array}{l}\text { Ольховский, } \\
\text { пос. Госконюшня }\end{array}$ & Меловые пещеры и святые источники \\
\hline $\begin{array}{l}\text { Гусевский Богородице-Ахтырс- } \\
\text { кий женский монастырь }\end{array}$ & $\begin{array}{l}\text { Ольховский, } \\
\text { с. Гусевка }\end{array}$ & $\begin{array}{l}\text { Ахтырская икона Божией Матери, привезенная из } \\
\text { Греции одним из основателей монастыря; частицы } \\
\text { мощей } 14 \text { Старцев Оптинских }\end{array}$ \\
\hline $\begin{array}{l}\text { Храм святого великомученика } \\
\text { Никиты Готфского }\end{array}$ & $\begin{array}{l}\text { Светлоярский, } \\
\text { с. Дубовый Овраг }\end{array}$ & $\begin{array}{l}\text { Мироточение плиточного пола (единственный в ми- } \\
\text { ре случай) и поновление икон; икона святого Ники- } \\
\text { ты Гофтского с частицей его мощей. Расположен в } \\
17 \text { км от Волгограда }\end{array}$ \\
\hline $\begin{array}{l}\text { Храм Покрова Пресвятой Бого- } \\
\text { родицы }\end{array}$ & $\begin{array}{l}\text { Среднеахтубинский, } \\
\text { пос. Средняя Ахтуба }\end{array}$ & $\begin{array}{l}\text { Представляет интерес как редкий образец храма, вы- } \\
\text { строенного и открытого в советский период (1984- } \\
1987 \text { гг.) }\end{array}$ \\
\hline
\end{tabular}

\footnotetext{
Примечание. Составлено автором по: [Волгоградская епархия].
}

К полупериферии относятся районы, где могут находиться очень ценные и значимые для паломников и туристов монастыри и храмы, но из-за того, что они размещены дисперсно и удалены на большое расстояние от Волгограда, маршруты с целью их посещения носят радиальный характер. К районам обозначенного типа можно отнести Камышинский, Серафимовичский, Урюпинский, Фролов- ский и т. д. В Покровском храме Урюпинска, уникальном для Волгоградской области уже потому, что в советский период он не был действующим только с 1930 по 1943 гг., пребывает чтимая икона Божией Матери Урюпинская, в день празднования памяти которой по православному церковному календарю (21 июня) ежегодно организуется паломнический тур из Волгограда. 
Периферию развития религиозного туризма в связи с редкой сетью православных храмов, удаленностью от центра и отсутствием на их территории значимых сакральных объектов составляют районы западной и южной части Волгоградской области.

Оценка потенциала Волгоградской области и дифференциация ее территории по степени развития здесь всех видов религиозного туризма способствует тому, чтобы выявить те районы и пункты, которые требуют максимального приложения усилий и вложения средств для успешного функциониро- вания данной отрасли рекреационного хозяйства, а также те из них, где развитие ее нецелесообразно.

Выявить факторы, способствующие развитию православного религиозного туризма в Волгоградской области, а также аспекты, которые его лимитируют, можно с помощью SWOT-анализа (табл. 3). Данный метод применялся в оценке потенциала развития отраслевого туризма [Орлова и др., 2014], но научные работы, где бы он использовался для исследования вопросов, связанных с видами религиозного туризма, отсутствуют.

Факторы, способствующие развитию православного религиозного туризма

Таблища 3

$$
\text { в Волгоградской области }
$$

\begin{tabular}{|c|c|}
\hline Сильные стороны & Слабые стороны \\
\hline $\begin{array}{l}\text { 1. Выгодное географическое положение («ворота»на } \\
\text { юг России с выходом на Кавказ, Украину и Казахстан, } \\
\text { в обратном направлении - на центральную Россию и } \\
\text { Поволжье. В области соединяются через Волг- } \\
\text { Донской канал две важнейшие реки Европейской час- } \\
\text { ти России - Волга и Дон). } \\
\text { 2. Наличие традиционных видов туризма: культурно- } \\
\text { познавательного, этнографического, круизного, рек- } \\
\text { реационно-лечебного (озеро Эльтон, богатое целеб- } \\
\text { ными солями и грязями), религиозного, рыбалки и др. } \\
\text { (на территории области есть семь природных парков- } \\
\text { «онской», «Щербаковский», «Цимлянские пески» } \\
\text { и др.). } \\
3 \text {. Богатое историко-культурное наследие (34 музея, } \\
923 \text { памятника архитектуры, } 1164 \text { памятника искусст- } \\
\text { ва и истории, более } 1500 \text { памятников природы). } \\
4 \text {. Более } 200 \text { православных храмов и часовен. } \\
\text { 5. Круизный паломнический туризм. } \\
6 . \text { Православная культура как средство самоидентифи- } \\
\text { кации населения районах проживания донских казаков } \\
\text { (Клетский, Михайловский, Урюпинский районы). } \\
\text { 7. Наличие сакральных для православных верующих } \\
\text { объектов (мощи местно чтимых святых, чудотворные } \\
\text { иконы, мироточение и т. д.) }\end{array}$ & $\begin{array}{l}\text { 1. Недостаточно развитая гостиничная инфраструктура. } \\
\text { 2. Отсутствие системы информационного ориентиро- } \\
\text { вания для туристов, пешех одной навигации, асиммет- } \\
\text { рия информации на сайтах паломнической службы и } \\
\text { туристических фирм, реализующих услуги религиоз- } \\
\text { ного туризма. } \\
\text { 3. Загрязнение рек, невыполнение экологического за- } \\
\text { конодательства. } \\
\text { 4. Формирование брендинга области преимуществен- } \\
\text { но на основе военно-патриотической тематики. } \\
\text { 5. Низкое качество сервиса туристических услуг. } \\
\text { 6. Недостаток специалистов в области туризма по раз- } \\
\text { работке новых маршрутов. } \\
\text { 7. Проблема обеспечения безопасности }\end{array}$ \\
\hline Возможности & \\
\hline $\begin{array}{l}\text { 1. Активное обновление транспортной инфраструкту- } \\
\text { ры, в том числе международного аэропорта, железно- } \\
\text { дорожного вокзала, сети маршругов городского } \\
\text { транспорта. } \\
\text { 2. Комплексное благоустройство территории в районе } \\
\text { строительства Нулевой продольной магистрали. } \\
\text { 3. Растущий интерес ко внутреннему туризму за счет } \\
\text { сокращения выездного потока туристов в условиях } \\
\text { экономического кризиса. } \\
\text { 4. Повышение уровня религиозности населения } \\
\text { (в рамках миссионерской деятельности РПЦ). } \\
\text { 5. Развитие религиозного туризма в сочетании с дру- } \\
\text { гими видами отраслевого туризма (военно- } \\
\text { патриотического, курортно-оздоровительного и т. д.) }\end{array}$ & $\begin{array}{l}\text { 1. Снижение круизного пассажиропотока. } \\
\text { 2. Конкуренция на рынке туристских услуг со стороны } \\
\text { городов Приволжского Федерального округа. } \\
\text { 3. Снижение привлекательности города в связи с не- } \\
\text { достаточным продвижением на международном и } \\
\text { внутреннем рынках туристских услуг. } \\
\text { 4. Конфликты вероисповеданий на территории посе- } \\
\text { ления приверженцев ислама. } \\
\text { 5. Политизация религиозных организаций. } \\
\text { 6. Действия религиозных сект и раскольничество }\end{array}$ \\
\hline
\end{tabular}

Примечание. Составлено автором. 
Результаты анализа позволяют говорить о том, что в Волгоградской области имеются серьезные предпосылки для развития религиозного туризма. В первую очередь, их создают православные часовни, храмы, монастыри и сакральные объекты поклонения, хранящиеся в них. Уникальность территории в плане развития данного направления туризма обусловлено ее географическим положением: именно здесь получил начало так называемый круизный паломнический туризм, то есть путешествие на переоборудованном под православный храм судне.

К факторам, лимитирующим развитие религиозного туризма в Волгоградской области, относятся низкий уровень развития туристской инфраструктуры и преимущество в туристском брендинге территории военно-патриотической тематики.

\section{Выводы}

Обобщая приведенные выше сведения и факты, можно заключить, что, несмотря на отсутствие древних памятников православной культовой инфраструктуры, Волгоградская область является примером региона, где религиозный туризм может выступать как значимая отрасль рекреационного хозяйства.

Для успешного развития религиозного туризма в Волгоградской области следует учитывать целый ряд условий и факторов. В первую очередь, нужно придерживаться стратегии укрепления уникальности предлагаемого продукта, ориентируясь на предъявителей целевого спроса, для которых эти особенные характеристики важны или приоритетны. К таковым относятся сакральные объекты (местночтимая икона Урюпинской Божией Матери, мощи местночтимых святых и связанные с их жизнеописанием вещи и т. д.) и явления (мироточение, поновление икон). Уникальные маршруты религиозной тематики можно осуществлять и с помощью круизов на судах-храмах, что на данный момент практически не нашло развития в других регионах России.

Донесение до реальных и потенциальных предъявителей спроса на религиозный туризм уникальных качеств территории Волгоградс- кой области в плане развития данного вида рекреационного хозяйства послужит формированию религиозного брендинга территории. В настоящий момент можно констатировать недостаток маркетинговых и брендинговых исследований в Волгоградской области, которые подчеркнули бы ее уникальные характеристики и послужили бы для привлечения туристов. Так, например, в регионе получил развитие так называемый событийный паломнический туризм, объективированный в крестных ходах. Импульс к развитию одного из направлений религиозного туризма может дать совмещение его с другими видами туризма (если учитывать исторические и природные составляющие рекреационного потенциала Волгоградской области, то в первую очередь с военно-патриотическим и курортно-оздоровительным).

Серьезные усилия следует сосредоточить на построении высокого уровня знания маршрутов и составляющих их объектов и на улучшении осведомленности об уникальных особенностях предлагаемой услуги.

Анализ предложения показал, что следует также диверсифицировать портфель предъявителей спроса на услугу религиозного туризма. Паломническая служба Волгоградской митрополии - основной игрок на этом рынке - предлагает туры с низким уровнем комфортности, цена которых близка к себестоимости, и ориентированные на покупателя с невысоким уровнем дохода, что разумно, учитывая актуальность этого фактора для региона, специфику контингента, пользующегося данной услугой (высокая доля пенсионеров). Немногочисленные фирмы-конкуренты, реализующие туры религиозной направленности, также не предлагают продукт для клиентов, менее чувствительных к цене, между тем это могло бы разнообразить предложение.

На данный момент религиозный туризм в Волгоградской области динамично развивается, о чем свидетельствует расширение географии, типов и тематики маршрутов православной направленности. Для его дальнейшего успешного функционирования в регионе следует принять меры для усиления преимуществ данного направления и к устранению выявленных недостатков. 


\section{СПИСОК ЛИТЕРАТУРЫ}

Артемьева, О. В. Дестинации религиозного туризма экскурсионно-познавательной направленности (на примере Ленинградской области) / О. В. Артемьева, О. А. Балабейкина // KANT. - 2019. - № 1. - С. 246-254.

Ванчикова, Е. Н. Маркетинговые исследования привлекательности развития религиозного туризма в республике Бурятия / Е. Н. Ванчикова, А. А. Цыренова // Известия Юго-Запад. гос. ун-та. Сер.: Экономика. Социология. Менеджмент. - 2014. - № 2. - С. 54-58.

Волгоградская епархия. - Электрон. текстовые дан. Режим доступа: http://volgeparhia.ru (дата обращения: 10.05.2019). - Загл. с экрана.

Галкова, О. В. Культовая архитектура Волгоградской области: история и современные проблемы изучения, сохранения и использования / О. В. Галкова, О. Н. Савицкая // Известия Волгогр. гос. пед. ун-та. - 2015. - № 2. - С. 171-178.

Единый паломнический центр Волгоградской митрополии. - Электрон. текстовые дан. - Режим доступа: http://palomnik-volgograda.ru (дата обращения: 20.05.2019). - Загл. с экрана.

Краснова, О. А. Религиозный туризм в Серафимовичском районе Волгоградской области / О. А. Краснова, Т. П. Назарова // Наука и молодежь: новые идеи и решения : материалы Х Междунар. науч.-практ. конф. молодых исследователей (г. Волгоград, 15-17 марта 2016 г.). - Волгоград : Изд-во ВолГУ, 2016. C. $46-47$.

Калинина, А. Э. Формирование системы муниципального управления Волгоградской области / А. Э. Калинина, А. В. Шевандрин; Федер. гос. бюдж. образоват. учреждение высш. проф. образования «Волгогр. гос. ун-т». Волгоград : Изд-во ВолГУ, 2011. - 198 с.

Крылов, А. Н. Сакральный туризм в концепциях развития городов и регионов / А. Н. Крылов / / Конкурентный потенциал региона: оценка и эффективность использования : сб. ст. междунар. науч.-практ. конф. (г. Абакан, 10-12 ноября 2011 г.). - Абакан : Изд-во Хакас. гос. унта им. Н. Ф. Катанова, 2011. - С. 14-16.

Лагусева, Н. Н. Паломничество и религиозный туризм: грани различия (размышления в рамках круглого стола) / Н. Н. Лагусева // Вестник Рос. междунар. акад. туризма. - 2017. - № 1.C. 95-101.

Оганесян, К. С. Роль религиозного туризма в международном туристском бизнесе / К. С. Оганесян // Молодой ученый. - 2013. - № 12. - С. 791-793.

Орлова, В. С. Перспективы развития лечебно-оздоровительного туризма в регионе / В. С. Орло- ва, А. А. Щербакова // Проблемы развития территории. - 2014. - № 4. - С. 34-47.

Пикулева, О. А. Религиозный туризм в системе брендинга территории (на примере Ленинградской области) / О. А. Пикулева // Вопросы гос. и муницип. упр. - 2012. - №4. - С. 194-205.

Сукманова, Н. Ю. Религиозно-познавательный туризм как фактор сохранения историко-культурного наследия Тверской области / Н. Ю. Сукманова // Соц.-экон. науки и гуманит. исслед. 2015. - № 9. - С. 70-75.

Соборы.Ру. Народный каталог православной архитектуры. - Электрон. текстовые дан. - Режим доступа: http://sobory.ru/epx/\#m1 (дата обращения: 22.05.2019). - Загл. с экрана.

Туризм Волгоград РФ. - Электрон. текстовые дан. Режим доступа: http://туризм-волгоград.рф (дата обращения: 04.06.2019). - Загл. с экрана.

Экскурсии и туры по Волгограду. - Электрон. текстовые дан. - Режим доступа: http:// www.excursions-volgograd.ru (дата обращения: 27.05.2019). - Загл. с экрана.

Якунин, В. Н. Религиозный туризм и паломничество: особенности организации, проблемы и перспективы развития / В. Н. Якунин // Культурное наследие России. - 2017. - № 1. - С. 71-76.

Griffin, K. The Importance of Religious Tourism and Pilgrimage: Reflecting on Definitions, Motives and Data / K. Griffin, R. Razaq // International Journal of Religious Tourism and Pilgrimage. 2017. - Vol. 5, iss. 3, art. 2. - DOI: https://doi.org/ 10.21427/D7242Z.

Puşcaşu, V. Religious Tourism or Pilgrimage? / V. Puşcaşu // European Journal of Science and Theology. 2015. - Vol. 11, № 3. - P. 131-142.

\section{REFERENCES}

Artemyeva, O.V., Balabeykina O.A. Destinatsii religioznogo turizma ekskursionno-poznavatelnoy napravlennosti (na primere Leningradskoy oblasti) [The Religious Tourism Destinations in the Excursionally-Cognitive Direction Area (On the Example of the Leningrad Region)]. KANT, 2019, no. 1, pp. 246-254.

Vanchikova E.N., Tsyrenova A.A. Marketingovye issledovaniya privlekatelnosti razvitiya religioznogo turizma $\mathrm{v}$ respublike Buryatiya [Research Development of Religious Tourism Attraction in the Republic of Buryatia]. Izvestiya Yugo-Zapadnogo gosudarstvennogo universiteta. Seriya: Ekonomika. Sociologiya. Menedzhment [Proceedings of South-West State University. Series Economy. Sociology. Management], 2014, no. 2, pp. 54-58. 
Volgogradskaya eparkhiya [Volgograd Diocese]. URL: http://volgeparhia.ru/ (accessed 10 May 2019).

Galkova O.V., Savitskaya O.N. Kultovaya arkhitektura Volgogradskoy oblasti: istoriya i sovremennye problemy izucheniya, sokhraneniya i ispolzovaniya [Cult Architecture of the Volgograd Region: History and Modern Issues of Study, Protection and Use]. Izvestiya Volgogradskogo gosudarstvennogo pedagogicheskogo universiteta [Ivzestia of the Volgograd State Pedagogical University], 2015, no. 2, pp. 171-178.

Edinyy palomnicheskiy tsentr Volgogradskoy mitropolii [Unified Pilgrimage Center of the Volgograd Metropolitan Area]. URL: http:// palomnik-volgograda.ru/ (accessed 20 May 2019).

Krasnova, O.A., Nazarova T.P. Religioznyy turizm v Serafimovichskom rayone Volgogradskoy oblasti [Religious Tourism in Serafimovichsky District of Volgograd Region]. Nauka $i$ molodezh: novye idei i resheniya: materialy $X$ Mezhdunar. nauch.-prakt. konf. molodykh issledovateley (g. Volgograd, 15-17 marta 2016 g.) [Science and Youth: New Ideas and Solutions. Proceedings of the $10^{\text {th }}$ International Scientific and Practical Conference of Young Researchers (Volgograd, March 15-17, 2016]. Volgograd, Izd-vo VolGU, 2016, pp. 46-47.

Kalinina A.E., Shevandrin A.V. Formirovanie sistemy munitsipalnogo upravleniya Volgogradskoy oblasti [Formation of the Municipal Management System of the Volgograd Region]. Volgograd, Izd-vo VolGU, 2011. 198 p.

Krylov A.N. Sakralnyy turizm v kontseptsiyakh razvitiya gorodov i regionov [Sacred Tourism in Urban and Regional Development Concepts]. Konkurentnyy potentsial regiona: otsenka $i$ effektivnost ispolzovaniya: sb. st. mezhdunar. nauch.-prakt. konf. (g. Abakan, 10-12 noyabrya 2011 g.) [Competitive Potential of the Region: Assessment and Efficiency of Use. Collection of Articles of the International Scientific-Practical Conference (Abakan, November 10-12, 2011]. Abakan, Izd-vo Khakasskogo gosudarstvennogo universiteta im. N.F. Katanova, 2011, pp. 14-16.

Laguseva N.N. Palomnichestvo i religioznyy turizm: grani razlichiya (razmyshleniya $\mathrm{v}$ ramkakh kruglogo stola) [Pilgrimage and Religious Tourism: The Verge of Distinction (Reflection in the Round Table)]. Vestnik Ros. mezhdunar. akad. turizma [Vestnik RIAT], 2017, no. 1, pp. 95-101.

Oganesyan K.S. Rol religioznogo turizma v mezhdunarodnom turistskom biznese [The Role of Religious Tourism in the International Tourism Business]. Molodoy uchenyy [Young Scientist], 2013, no. 12, pp. 791-793.

Orlova V.S., Shherbakova A.A. Perspektivy razvitiya lechebno-ozdorovitel'nogo turizma $\mathrm{v}$ regione [Prospects of Health and Recreation Tourism Development in the Region]. Problemy razvitiya territorii [Problems of Territory's Development], 2014, no. 4, pp. 34-47.

Pikuleva O.A. Religioznyy turizm v sisteme brendinga territorii (na primere Leningradskoy oblasti) [Religious Tourism in the Branding System of the Territory On the Example of the Leningrad Region)]. Voprosy gosudarstvennogo $i$ munitsipalnogo upravleniya [Public Administration Issues], 2012, no. 4, pp. 194-205.

Sukmanova N.Yu. Religiozno-poznavatelnyy turizm kak faktor sokhraneniya istoriko-kulturnogo naslediya Tverskoy oblasti [Religion-Cognitive Tourism as a Factor of Historical and Cultural Heritage Preservation in the Tver Region]. Sots.-ekon. nauki i gumanit. issled, 2015, no. 9, pp. 70-75.

Sobory.Ru. Narodnyy katalog pravoslavnoy arkhitektury [Sobory.Ru. National Catalogue of Orthodox Architecture]. URL: http://sobory.ru/ epx/\#m1 (accessed 22 May 2019).

Turizm Volgograd RF [Tourism Volgograd Russian Federation]. URL: http://туризм-волгоград.pф (accessed 4 June 2019).

Ekskursii i tury po Volgogradu [Excursions and Tours in Volgograd]. URL: http://www.excursionsvolgograd.ru/ (accessed 27 May 2019).

Yakunin V.N. Religioznyy turizm i palomnichestvo: osobennosti organizatsii, problemy i perspektivy razvitiya [Religious Tourism and Pilgrimage: Features of the Organization, Challenges and Prospects]. Kulturnoe nasledie Rossii [Cultural Heritage of Russia], 2017, no. 1, pp. 71-76.

Griffin K., Razaq R. The Importance of Religious Tourism and Pilgrimage: Reflecting on Definitions, Motives and Data. International Journal of Religious Tourism and Pilgrimage, 2017, vol. 5, iss. 3, article 2. DOI: https://doi.org/ 10.21427/D7242Z.

Puşcaşu V. Religious Tourism or Pilgrimage? European Journal of Science and Theology, 2015, vol. 11, no. 3, pp. 131-142. 


\section{РЕГИОНАЛЬНАЯ ЭКОНОМИКА}

\section{Information About the Author}

Olga A. Balabeykina, Candidate of Sciences (Geography), Associate Professor, Department of Regional Economics and Natural Resource Management, Saint Petersburg State University of Economics, Sadovaya St., 21, 191023 Saint Petersburg, Russian Federation, olga8011@yandex.ru, https://orcid.org/0000-0001-9520-8880

\section{Информация об авторе}

Ольга Александровна Балабейкина, кандидат географических наук, доцент кафедры региональной экономики и природопользования, Санкт-Петербургский государственный экономический университет, ул. Садовая, 21, 191023 г. Санкт-Петербург, Российская Федерация, olga8011@yandex.ru, https://orcid.org/0000-0001-9520-8880 